\title{
International entrepreneurship at the crossroads between innovation and internationalization
}

\author{
Birgit Hagen • Stefano Denicolai • \\ Antonella Zucchella
}

Published online: 16 July 2014

(C) Springer Science+Business Media New York 2014

In the last years, the global economy has undergone a dramatic change. Developed economies face the challenge of new players from emerging countries, slow growth problems, and even recession, combined with a weaker entrepreneurial activity (Amoros and Bosma, 2014). This new economic order calls for a significant reshaping of competition, which leverages on the interplay of the discovery/enactment of new opportunities, the ability to create innovative value propositions and lead them to success, and the capacity to mobilize and manage resources at the global level. In other words, this new economic landscape requires a combination of entrepreneurship, innovation, and internationalization.

Internationalization and innovation are two major options to achieve firm growth. Traditionally, these two routes to growth have been studied separately and only recently innovation and internationalization are increasingly seen as being strongly interrelated, with entrepreneurship representing the trait d'union between the two (Onetti et al. 2012; Etemad and Keen, 2012; Zucchella and Siano 2014). Entrepreneurial posture and the attitude to change and innovation play a central role in the internationalization process of both established firms and born global firms, especially in new, rapidly changing environments. However, the intersection of innovation, internationalization, and entrepreneurship is a field of study with a number of research gaps. In the first place, the causal relationship between innovation and internationalization is controversial. A large body of literature argues that international firms tend to exploit their superior innovative capabilities in several markets (e.g., Pla-Barber and Alegre, 2007; Kafouros et al., 2008; Cassiman and Golovko, 2011; Denicolai et al., 2014). According to other scholars, the relationship between innovation and internationalization is almost insignificant, and even negative (e.g. Hitt et al. 1997). Secondly, much of the international new venture literature is implicitly based on innovative and high-technology firms, the role of innovation in other sectors and in different typologies of international entrepreneurship (for example, immigrant entrepreneurs), types of business models which enhance the interplay between internationalization and innovation, etc. remain under-investigated.

B. Hagen $(\bowtie) \cdot$ S. Denicolai $\cdot$ A. Zucchella

Department of Economics and Management, University of Pavia, Via San Felice 7, 27100 Pavia, Italy e-mail: bhagen@eco.unipv.it 
In short, we need further contributions aimed at clarifying the nature, trends, and dynamics of international entrepreneurship. These considerations started with the 15 th McGill International Entrepreneurship Conference and led to this special issue, consisting of five papers.

The article by Gray and Farminer aims to contribute to the ongoing debate over the nature and future directions of international entrepreneurship (e.g., Jones et al. 2011; Keupp and Gassmann, 2009) and its linkage with innovation in particular. They approach this goal through a "review of reviews" of recent International Entrepreneurship (IE) studies as well as a census of the articles published in the Journal of International Entrepreneurship between its inception in 2003 until the beginning of 2012. The authors highlight the convergence with regard to IE's positioning at the intersection of entrepreneurship and IB studies, but they also highlight the gap relative to a second intersection, which is the focus of this special issue. As mentioned above, the authors emphasize the need for a clarification of the links among entrepreneurship, innovation, and internationalization. Gray and Farminer extend Rialp et al.'s (2005) question from "...early internationalizing firms: what do we know after a decade of scientific inquiry" to "what do we know about the dynamics and patterns of INV creation, innovation and internationalisation after two decades of scientific inquiry" and provide further evidence for a general lack of longitudinal studies, which is also reflected in recent special issues of IMR and MIR (Hagen and Zucchella 2014), respectively. In particular, the authors note that only a few studies are concerned with firm lifecycles, the aspects of business model creation and evolution, studies of dynamic capabilities, collaborative approaches, and social networks leading to innovation and value creation. This special issue contributes to the debate of issues raised by Gray and Farminer and others. Studies in this issue adopt different perspectives and methods, but they share the goal of bringing together entrepreneurship, international business, innovation, and economic development.

What happens after the inception of international new ventures (INVs) has received limited research attention but it is crucial to our understanding of the entrepreneurial process and entrepreneurial activities as a whole (Liesch et al., 2007). The contribution by Turcan and Juho adopts this longitudinal view under the dynamic capability perspective. Grounded in data of a single exploratory case study, they investigate "made-it-points," defined as the entrepreneurial threshold whereby INVs undergo a transition from emergence to the professional management stage (Zahra and Filatochev 2004). To get to a "made-it-point," Turcan and Juho find the entrepreneurs to "create, re-create, conceptualize and re-conceptualize, contextualize and re-contextualize the type and the elements of their venture...to generate new value-creating strategies". In other words, the entrepreneurs experiment with their venture at organizational, business model, and operational levels. These experimentations are essentially fueled by the need for change and innovation related to ownership structures, business propositions to the market, and product development processes.

A second perspective in understanding the growth and the sustainable competitive advantage over time of international entrepreneurial and innovative ventures is the model of business adopted. The linkages of this topic to the innovation, internationalization, and entrepreneurship nexus have been outlined in a special issue of the Journal of Management and Governance in 2012 (Onetti et al. 2012), which calls for more research in this field. The contribution by Rask offers a fruitful conceptual study in this 
direction. By outlining four types of business models, he discusses a fine-grained picture of this kind of innovation by highlighting its international dimensions. In particular, the author provides evidence which suggests that a business model varies depending on the configuration of the value creation architecture at the upstream level (e.g., domestic production vs global factory) and at the downstream level in the target markets (e.g., domestic vs international markets). This leads to four models showing diverse resource allocation policies in order to deal with differences among geographical locations. Also, the longitudinal dimension is taken into account since the four models relate to different entry mode elements. Rask analyzes how these dimensions and elements are interrelated in a firm's entrepreneurial and international activities, focusing on the assumption that the location advantage tends to be a critical ingredient for innovation at the business model level, at both upstream and downstream levels.

A sustainable business model as proposed by strategists such as Teece (2010) and Chesbrough (2010) implies that innovation and value is created by a firm for its customers, while a new dominant logic of marketing suggests that value is often cocreated by customers and firms (Vargo and Lusch, 2004). Such a collaborative approach to innovation and value creation is illustrated by Lofgren. She studies coinnovation within a dyadic business relationship with a key customer and looks into the outcomes in the focal business relationship and in the small firm's foreign expansion. The knowledge that small and medium enterprises (SMEs) can access from their customer relationships is central to a firm's innovation (e.g., Yli-Renko et al. 2002; Presutti et al. 2007) as well as to its internationalization processes (e.g., Sharma and Blomstermo, 2003). Lofgren adds to our knowledge on the combination and the management of knowledge and learning from customer relationships and business networks in general. Results of a LISREL structural equation modeling on 188 international SMEs show that the firm's awareness of the customer's complementary knowledge and innovation-oriented customer relationships lead to increased coinnovation. Lofgren also shows that successful co-innovation raises the likelihood of using the key customer as a bridge to new customers and suppliers on the foreign market. As such, her findings establish a link between innovation and internationalization through the mediating role of co-innovation.

Vissak and Zhang consider a relatively unexplored field, represented by innovation and international entrepreneurship, the latter characterized by immigrant entrepreneurs. This is a relevant topic in the field to be discussed here. Indeed, the fast growth of "wannabe" expatriate entrepreneurs looking for the best place to start a new venture and innovate is attracting the attention of policy makers and scholars (Parrotta et al. 2014). For instance, the USA has introduced the so-called start-up visa to meet requirements of this class of immigrants. From a scientific perspective, it is an interesting case where entrepreneurship, internationalization, and innovation tend to be "naturally" intertwined, thus supporting a better understanding of these dynamics. In particular, the study of Vissak and Zhang investigates the roles of Chinese immigrant entrepreneurs in their firms' international and innovative activities in Canada, China, and other countries. Findings of the case study analysis show that a better understanding of knowledge management at the global level implies a more complex framework. Knowledge exchanges across countries are crucial for opportunity identification, adaptation decisions, and linkages between social networks and entrepreneurship mobility. Evidences also show that the social network could be the abovementioned trait d'union between 
internationalization and innovation, since the interpersonal connections developed in a new market, coupled with the strategic ones in the native country, foster the learning process, thus stimulating innovation. Moreover, findings suggest that the cognitive distance with respect to the market in which the entrepreneur considers entry supports a different view on business opportunities. Once again, the longitudinal evolution of such ties emerges as a key consideration.

These five contributions not only offer insights to the abovementioned research gaps, but they also introduce new arguments and promising research areas. They support that the "International Entrepreneurship and innovation" stream is only at its infant stage, thus introducing auspicious opportunities for scholars in the field.

\section{References}

Amoros J. Bosma N (2014) Global Entrepreneurship Monitor-2013 Global Report-Fifteen Years of Assessing Entrepreneurship Across the Globe, Universidad del Desarrollo and Global Entrepreneurship Research Association.

Cassiman B, Golovko E (2011) Innovation and internationalization through exports. J Int Bus Stud 42:56-75

Chesbrough H (2010) Business model innovation: opportunities and barriers. Long Range Plan 41(2-3):354-363

Denicolai S, Zucchella A, Strange R (2014) Knowledge assets and firm international performance. Int Bus Rev 23:55-62

Etemad H, Keen C (2012) Rapid growth and rapid internationalization: the case of smaller enterprises from Canada. Manag Decis 50:569-590

Hagen B, Zucchella A (2014) Born global or born to run? The long-term growth of born global firms. Management International Review, forthcoming.

Hitt MA, Hoskisson RE, Kim H (1997) International diversification: effects on innovation and firm performance in product-diversified firms. Acad Manag J 40(4):767-798

Jones MV, Coviello N, Tang YK (2011) International Entrepreneurship research (1989-2009): a domain ontology and thematic analysis. J Bus Ventur 26:632-659

Kafouros MI, Buckley PJ, SHARP JA, Wang C (2008) The role of internationalization in explaining innovation performance. Technovation 28:63-74

Keupp MM, Gassmann O (2009) The past and the future of international entrepreneurship: a review and suggestions for developing the field. J Manag 35:600-633

Liesch P, Weerawardena J, Sullivan-Mort G, Knight G, Kastelle T (2007) Introduction. J World Bus 42(3): 232-235

Onetti A, Zucchella A, Jones MV, Mcdougall-Covin PP (2012) Internationalization, innovation and entrepreneurship: business models for new technology-based firms. J Manag Gov 16:337-368

Parrotta P, Pozzoli D, Pytlikova M (2014) The nexus between labor diversity and firm's innovation. J Popul Econ 27:303-364

Pla-Barber J, Alegre J (2007) Analysing the link between export intensity, innovation and firm size in a science-based industry. Int Bus Rev 16:275-293

Presutti M, Boari C, Fratocchi L (2007) Knowledge acquisition and the foreign development of high-tech start-ups: a social capital approach. Int Bus Rev 16(1):23-46

Rialp A, Rialp J, Knight G (2005) The phenomenon of early internationalizing firms: what do we know after a decade (1993-2003) of scientific inquiry? Int Bus Rev 14(2):147-166

Sharma D, Blomstermo A (2003) The internationalization process of born globals: a network view. Int Bus Rev 12(6):739-753

Teece D (2010) Business models, business strategy and innovation. Long Range Plan 43(2-3):172-194

Vargo S, Lusch R (2004) Evolving to a new dominant logic for marketing. J Mark 68(1):1-17

Yli-Renko H, Autio E, Sapienza H (2002) Social capital, knowledge acquisition and the International growth of technology-based new firms. Int Bus Rev 11(3):279-304

Zahra S, Filatochev I (2004) Governing the entrepreneurial firm: a knowledge based view. J Manag Stud 41: 885-898

Zucchella A, Siano A (2014) Internationalization and innovation as resources for SME growth in foreign markets: a focus on textile and clothing firms in the Campania Region. Int Stud Manag Organ 44:21-41 